vated plants, and the association of certain important biological characters with polyploidy, led to speculation about the possible application of artificially inducing polyploids-both autopolyploids and allopolyploids-to plant breeding. The cytogenetic department at Svalof developed these ideas, and with the discovery of the colchicine technique considerable impetus was given to both the fundamental scientific aspects and the breeding approach. In addition, work was developed on the artificial induction of mutations, a problem which had attracted Nilsson-Ehle since his studies of naturally occurring mutant forms in wheat, barley and rye, and on which he had published many papers.

After his retirement, Nilsson-Ehle continued to be actively interested in plant-breeding. It was due to his energetic interest that institutes for the improve. ment of forest trees and fruit trees were founded, while he himself devoted time to the breeding of the giant aspen. His great energies and capacity for work have left their mark on scientific research, on agriculture through crop improvement, and on the institutes which he guided. In the academic sphere his long association with the lecture room and laboratory inspired and stimulated a great number of students and research workers who came under his influence, and it is gratifying to know that his name was honoured by the creation of a fund in 1943, the revenue from which will be used for stimulating genetics research. G. D. H. BeLI

\section{Prof. G. H. Livens}

Wiтн the unexpected death of Prof. G. H. Livens on March 26, the University College of South Wales and Monmouthshire, Cardiff, has lost not only a distinguished mathematician, but also one who has rendered valuable service to the College for the long period of twenty-seven years.

Born in 1886, he received his early education at the Latymer Upper School, Hammersmith, before proceeding to Jesus College, Cambridge. At Cambridge he had a distinguished career, being bracketed fourth wrangler in Part I of the Mathematical Tripos of 1909 , the last year in which the lists were published in order of merit, and being placed in Class I, Division 2, in Part II in 1910. In 1911 he was awarded the first Smith's Prize, and in the same year he was elected a Fellow of Jesus College.

Meanwhile he had been appointed lecturer in geometry at the University of Sheffield, where he stayed until 1919, when he became senior mathematical lecturer at the University of Manchester. $\mathrm{H}_{\Theta}$ was elected to the chair of mathematics at Cardiff in 1922 .

It was during his period in Sheffield that Prof. Livens started to publish numerous papers on electrical theory, and his "Theory of Electricity" was first published in 1918. Later he published papers in many branches of applied mathematics, but chiefly in electrical theory, magnetism and thermodynamics.

In educational affairs generally, Prof. Livens took a very active part. Besides his departmental duties, he gave loyal service in the faculties and the Senate, and in the many committees on which he served he was always much esteemed, not only for his personal integrity and sincerity, but also for the valuable contributions he made to the business under discussion. His decisions were made without prejudice, and with no thought of personal interest.
Prof. Livens's interests extended beyond the University, however, in many directions-to the mathematical courses in the Welsh training colleges, to the Central Welsh Board as an examiner and adviser for many years, to the local branch of the Mathematical Association-and it may well be said that he did great service in guiding the development of the study of mathematics in Wales. His value as an examiner is also shown by the fact that he was an external examiner for the University of London from 1929 until his death.

Prof. Livens will be remembered with affection by many generations of students who always found him willing to be helpful; his staff will remember with gratitude his continual readiness to discuss all aspects of thoir deppartmental and research work, and also the value of his advice and guidance.

\section{R. M. MorrIs}

\section{Dr. F. W. Foxworthy}

Dr. Fred WILliam Foxworthy, forest research officer during 1918-32 in the Federated Malay States, died suddenly in Berkeley, California, on February 4. $\mathrm{He}$ was the younger son of a Methodist minister, and was born on July 7, 1877, at Goodland in the State of Indiana. His education to 1899, when he graduated in science at the De Pauw. University, was within his native State; then he proceeded to Cornell, where he was given a teaching post and took the degree of Ph.D. in botany (1902). Many knew him in those college days as a boxer, a football player and a redoubtable baseball player. In 1906 he was appointed a botanist in the Bureau of Science, Manila, and gradually became a forester: a dominating interest in the ecology of the forests led to it.

The trees having determined his bent, he was made wood technologist in the Bureau and associate professor of dendrology in the University of Manila. It was natural that he should turn from the Philippine forests to compare them with those of other parts of Malaysia ; and, with the conservator of forests, British North Borneo, he published in 1917 an account of the mangrove and nipa swamps of northern Borneo through which runs a comparison of these formations in the two places. In 1918 he accepted the appointment of forest research officer under the Government of the Federated Malay States. This new post brought to him unrivalled opportunities for work; and he used them to great advantage: splendid undamaged forests were coming under control, and the large active staff controlling them was ripe to aid in collecting specimens and making observations; his part was to sift, to direct and to attach the technology to the botany. Building up a small museum of forest products and a forest herbarium, he had by 1927 materials for his "Commercial Timbers of the Malay Peninsula" (Mal. For. Rec., No. 5) and, on a narrower front, by 1932, materials for his "Dipterocarpace» of the Malay Peninsula" (Mal. For. Rec., No. 10) : at various dates there were less exacting publications. The second of the two named greatly advanced our precise knowledge of the chief sources of Malayan timber.

Retired at his age limit, Dr. Foxworthy went back to the United States and, marrying, settled at Berkeley, California, living actively, teaching, writing, joining in the scientific life of the neighbourhood of San Francisco, and during the Second World War called to war work. In 1936 he was president of the California Botanical Society. Later he wrote for the 